\title{
The Influence of RET's on Elementary and Secondary Grade Teachers' Views of Scientific Inquiry
}

\author{
Sibel Bahbah ${ }^{1}$, Barry W. Golden ${ }^{2}$, Katrina Roseler ${ }^{1}$, Patrick Elderle $^{3}$, Yavuz Saka ${ }^{4} \&$ Sherry A. Shoutherland ${ }^{5}$ \\ ${ }^{1}$ Office of Science Teaching Activities, 1062 C Life Building, Florida State University, Tallahassee, USA \\ ${ }^{2}$ Science Education in the Department of Theory and Practice in Teacher Education, University of Tennessee \\ Knoxville College of Education, Health, and Human Sciences, A404 Bailey Education Complex, Knoxville, \\ USA \\ ${ }^{3}$ Science Education/ADI Implementation Project Learning Systems Institute, The Florida State University, \\ Tallahassee, USA \\ ${ }^{4}$ Bulent Ecevit University/ Eregli Faculty of Education, Eregli, Zonguldak 67300, Turkey \\ ${ }^{5}$ FSU-Teach Florida State University, 203 Carothers, Tallahassee, Florida, USA \\ Correspondence: Sibel Bahbah, Office of Science Teaching Activities, 1062 C Life Building, Florida State \\ University, Tallahassee, FL 32306, USA. Tel: 1-480-275-1710. E-mail: sibel.uysal@gmail.com
}

\author{
Received: October 29, 2012 Accepted: November 6, 2012 Online Published: December 4, 2012 \\ doi:10.5539/ies.v6n1p117 URL: http://dx.doi.org/10.5539/ies.v6n1p117
}

The research is financed by the National Science Foundation, DISCOVERY RESEARCH K-12 Program, award number $\# 0553769$

\begin{abstract}
This study explores in-service elementary and secondary science teachers' conceptions of the Nature of Scientific Inquiry and the influence of participation in two different Research Experience for Teacher (RET) programs had on these conceptions. Participant teachers attended one of two six week RET programs in which they worked with scientists to engage in scientific inquiry. Before and after the RETs, teachers completed the Views of Scientific Inquiry (VOSI) questionnaire. Teachers' answers were analyzed to determine the degree of sophistication of their understanding of five facets of scientific inquiry. Both elementary and secondary teacher participants showed improvement in their understanding of nature of scientific inquiry as a result of program participation, and both programs were successful in supporting the development of inquiry conceptions, although secondary science teachers started and finished the RET's with a more sophisticated understandings of scientific inquiry. Areas of improvement for elementary teachers included the role of questions in science and the role subjectivity and creativity play in the processes of science, and for secondary teachers growth was seen in the role of questions, the relationship of data and evidence, the distinction of experiments and other means of investigations, and the varied methods of science. Implications of these results are discussed.
\end{abstract}

Keywords: nature of scientific inquiry, professional development workshop

\section{Introduction}

As described by the National Research Council, to be considered "fully proficient in science" students must be able to (1) know, use, and interpret scientific explanations; (2) generate and evaluate scientific evidence and explanations; (3) understand the nature and development of scientific knowledge; and (4) participate productively in scientific practices and discourse (Duschl et al., 2007). Students' understanding and ability to conduct scientific inquiry is central to each of these strands of scientific proficiency. One of the most direct ways of supporting the development of these proficiencies involves allowing students to participate in classroom inquiry.

Despite being a major focus for science educators and teachers over many years due to its promise for enhancing student learning, the implementation of inquiry in K-12 science classrooms has developed in an inconsistent manner and met with limited success. A host of reasons exists for this omission, which includes the limited time to teach broad curricula required by accountability demands, a lack of materials, a lack of pedagogical 
knowledge for inquiry, and scant curricular materials (Abrams, Southerland \& Silva, 2008). Among these barriers to classroom inquiry and perhaps one of the most influential barriers is teachers' limited knowledge of scientific inquiry. Simply put, it is difficult to teach what one does not understand, and just as this is true for views of the nature of science (Blanchard, Southerland \& Granger, 2009), there is substantial evidence to suggest that most science teachers do not have an adequate understanding of scientific inquiry - that is they do not understand how science is done.

According to Schwartz, Lederman and Lederman (2008), an understanding of scientific inquiry "relates to what/why scientists work as they do and how that knowledge is accepted within the scientific community" (p. 2). The understanding of the nature of scientific inquiry (NOSI) is often conflated with the nature of science (NOS), with the key distinction being that while the nature of science focuses on the products of inquiry, the nature of science inquiry focuses on the process of inquiry (Schwartz et al., 2008).

Just as distinctions should be drawn between teachers' understanding of NOS and NOSI, it is necessary to distinguish between teachers understandings and enactment of classroom inquiry and their understandings of scientific inquiry. Although a significant body of research exists concerning teachers' abilities to enact inquiry in the classroom (Abrams et al., 2008; Capps, Crawford, \& Constas, 2012), far less research explores teachers' understanding of scientific inquiry (Schwartz et al., 2008). While one's understanding of scientific inquiry may influence their knowledge of classroom inquiry, it is important to recognize that these two are interrelated but distinct constructs. Schwartz et al. (2008) describe that the general concepts addressed in a robust understanding of scientific inquiry include:

1) Questions guide investigations

2) There are multiple methods of investigation

3) There are multiple purposes of scientific investigations

4) Justification for scientific knowledge

5) Recognition and handling of anomalous data

6) Resources, roles and distinctions between scientific data and evidence

7) The community of practice of science.

Although scientific inquiry is a unique construct, teachers' understanding of NOSI can be enhanced through concerted professional development. Lederman and Lederman (2008) in their case study of an elementary teacher's growth during professional development targeting the nature of science and scientific inquiry describe that at the outset of instruction, the teacher understood science to require a linear, step-by-step process that is controlled and objective, leading to a singular correct answer. After participation in project ICAN, the teacher came to understand that there is no universal step-by-step scientific method and that there are multiple methods accepted in science. She also came to understand that science begins with a question that then guides the procedures used in its investigation.

Cakir (2004) examined the development of preservice secondary science teachers' understanding of nature of science and scientific inquiry (NOS and NOSI) as a result of engagement with a computer simulation targeting Mendelian genetics concepts. Before participation, the teachers held uninformed understandings of these constructs. Afterwards, the participants developed a more informed understanding along the following lines: (a) the iterative nature of scientific inquiry; (b) the tentativeness of specific knowledge claims; (c) the degree to which scientists rely on empirical data, as well as broader conceptual and metaphysical commitments, to assess models and to direct future inquiries; (d) the need for conceptual consistency; (e) multiple methods of investigations and multiple interpretations of data; and (f) social and cultural aspects of scientific inquiry. Again, professional development experiences evince promise in developing two specific aspects of a teachers' views of scientific inquiry-specifically that there are multiple methods of investigations and multiple valid interpretations of a data set.

Traditional conceptualizations of science are not held only by educators. Kennedy, Yezierski, and Herrington (2008) demonstrated that chemistry college faculty, undergraduate science majors and chemistry teachers hold a deep understanding of content although they maintain naïve conceptions of a singular scientific method and the idea that the processes of science properly followed allow for the identification of a 'truth' about nature. These results provide evidence that understandings of scientific inquiry develop separately from understanding of science content knowledge. 
Although work focusing on learner's understandings of scientific inquiry is far more sparse than work focusing on the nature of science (Khishfe \&Abd-El Khalick, 2002), scholars acknowledge that the two can and should go "hand in hand" in instruction (Lederman \& Lederman, 2008). If the teacher education community is to help prepare teachers to structure science instruction in ways that will enhance students' science proficiency, we must focus on ways to support teachers' development of their knowledge in this area. Further research remains necessary in describing teachers' understandings of the processes of science, the way in which science develops the knowledge it produces, as well as describing the effectiveness of professional development efforts in shaping teachers' knowledge in this area (Capps et al., 2012).

One form of professional development that has particular promise in shaping teachers' understanding of scientific inquiry involves Research Experience for Teachers (RET), often supported by the National Science Foundation. Many RET programs now exist and nearly as many different strategies are used by those programs to support teachers' needs (Granger \& Hernkind, 1999). The traditional format is for the RET to place teachers in the research lab of a practicing scientist (Schwartz, Westerlund, Garcia, \& Taylor, 2010). Another, less common format for an RET experience combines science content experience with immersion in a model of inquiry-based science teaching (Blanchard et al., 2009). The difference between the two models concerns the relative weight each places on engaging in scientific research versus an emphasis on understanding the role of scientific inquiry in meaningful science teaching. Although different approaches may produce different benefits for teachers, the impact of these different models on teachers' understanding of scientific inquiry remains unknown and serves as the focus of the study described here.

\section{Research Question}

As part of a larger research project, in this research we sought to describe how participation in two contrasting RET programs supported the development of teachers' understandings of the NOSI. In this effort our research questions included:

1) Does participation in a Research Experience for Teachers Program shape science teachers' understandings of scientific inquiry?

2) What are the patterns of change in teachers' understanding of scientific inquiry as a result of participation in RET programs?

3) Is there a difference in the effectiveness of two different models for RET programs (SciPed and SciRes) in shaping elementary and secondary teachers' understanding of scientific inquiry?

\section{Methods}

This research project is part of a larger project examining the influence of RET programs on teachers knowledge, beliefs and classroom practices (see Golden et al., 2011 for an extended examination of the wider study). The research examined here used data gathered from teachers before and after participation in one of two RET professional development experiences to track the changes in their understandings of scientific inquiry

\section{Contexts: Contrasting RET Programs}

The regional location of the study centers on a large research extensive university in the Southeast United States. The university in which this study took place is home to two different approaches to Research Experience for Teachers, the Science Research Model and the Science Pedagogy Model.

\subsection{Science Research (SciRes) RET Model}

Funded by the NSF (supplement to DMR-0084173), this RET program has attracted teachers from eight states. Fifty-six scientists and researchers have served as mentors. The primary focus of the SciRes RET program involves participation in authentic, engaging scientific research. While offering many opportunities for teachers to learn about frontier science and/or rejuvenate their interest in science, the explicit focus on translating these experiences into teachers' practice is precluded by their intense research contexts. The SciRes RET model closely resembles the structure of many RET's nationwide. At the initial stages of this research, the director of the program outlined that the goal of the program is

... to provide teachers with a real world research experiences. So, the purpose as far as the Center is concerned is to get teachers involved in real research, not a project but real research. Sometimes, that is doing part of what the researchers are already doing in their lab. And sometimes, the researcher and the teacher come up with the project. They can do while they are here but it has to be research-based. (Director of SciRes Model, personal interview) 
All participating teachers are placed in one facility, the International Magnetic Laboratory (IML), for 6 weeks during the summer. A typical day consists of 6 hours in the laboratory and 2 hours in one of the following activities: science seminar, colloquium, workshop-type teaching sessions, strategy sharing, or peer mentoring. On a weekly and rotating basis, the participants are asked to conduct an inquiry lesson from their own classrooms with the others, and a reflective discussion about the activity follows.

Having teachers participate in authentic, on-going scientific research is the primary goal for the program, and because there is such a wide variety of research conducted at the IML, teachers are exposed to diverse research areas. Research at the IML spans all disciplines of science-biology, chemistry, physics, medicine, earth science-and, while teachers work in only one lab, through the seminars and colloquia, they are exposed to research from all areas of the laboratory. Additionally once during their time at the ILM, individual teachers engage the rest group a tour of their laboratory space and describe the nature of their work and research in that space.

\subsection{Science Pedagogy (SciPed) RET Model}

Developed with funding from the NSF (ESI-9819431), the SciPed Model engages teachers in scientific research and an in-depth study of what this means for their teaching practice. During the past several years, over 120 elementary-, middle-, and high-school teachers have participated in the SciPed RET program. This RET was designed with the assumption that research experience offered in tandem with reflection on the teaching of inquiry is essential for teachers to internalize aspects of inquiry.

In the SciPed model, a veteran research scientist and one master teacher are involved full-time for 6-weeks working alongside participating teachers in all research and pedagogy sessions. Teachers experience all stages of scientific inquiry including original observation of a scientific phenomenon; development of their own research questions and hypotheses about it; development of the research methodology to test their hypotheses; the process of research; data organization and analysis; and reporting of results.

Specifically, the SciPed RET provides teachers with experience in making original observations on marine organisms to arouse their curiosity. They perform short-term research in ecology and ethology, research that does not require extensive prior subject-matter expertise on their part or complicated instrumentation. Structured inquiry, facilitated by program staff, begins with the teachers' observations, extends through hypothesis development and testing, data analysis, interpretation, and reporting of results. The scientists guide but do not prescribe the research process, so each individual makes an intellectual investment in the discovery of knowledge that is new to the teacher (if not to science). Drawing from their science research, teachers engage in reflection upon the pedagogical features of their research experience using a hermeneutic dialectic (discussion / journal writing / written instructor responses / discussion / journal clarification / written instructor responses) process. A master teacher, a facilitator in the program, explained the goal of the program as "to help teachers implement more inquiry-based teaching into their teaching practice" (Master teacher, OSTA, personal interview).

\subsection{Participants}

This study was conducted on three cohorts of elementary and secondary teachers who participated in the programs during the summers of 2008, 2009 and 2010. (See table 1). The average number of years of teaching experience for the group approached 9 years, with most participants coming into the programs with 4 years of experience. In terms of gender, 53 participant teachers were female and 35 of them were male teachers. The group was also diverse in terms of the amount and nature of professional preparation and professional development experienced. The one factor that spans each of them was their willingness to engage in extensive professional development as represented by their application to the RET programs.

Table 1. Grade level distribution of teacher participants

\begin{tabular}{llll}
\hline Grade Level & SciPed & SciRes & Total \\
\hline Elementary & 11 & 11 & 22 \\
Secondary & 18 & 15 & 33 \\
Total & 29 & 26 & 88 \\
\hline
\end{tabular}




\subsection{Data Collection}

Data were collected using the Views of Scientific Inquiry (VOSI) instrument appropriate for their grade level teaching placement. The VOSI is a multi-item open-ended survey that measures a range of conceptions related to scientific inquiry developed by Schwartz et al (2008). (See Appendix A for the survey.) The version of the survey employed for this study assessed five aspects of teachers' understanding of the nature of scientific inquiry (role of questions in guiding scientific investigations, relationship between data, analysis and evidence, experiments' distinction from other forms of investigation, role of subjectivity and creativity in scientific procedures and the varied methods of science).

Each participant completed the survey before beginning the professional development experience, then again 10 weeks after completion of the program.

\subsection{Data Analysis}

To assess the open-ended VOSI items for the elementary and secondary instruments, the research team developed a scoring rubric. The researchers, after piloting the rubric with an initial set of VOSI responses, employed a 3 level scoring system to categorize the responses. The three levels were: Naïve, Informed and Sophisticated. Each level scored from 1, 2 and 3 respectively to code each VOSI response. At the outset of coding, two researchers scored each participant's answers separately, then met to discuss their results. The first round of data analysis on 20 surveys resulted in a low inter-rater reliability, as measured by Cohen's Kappa (1968) (0.48). Further iterations of this process allowed for modification and refinement, developing consensus around a final version of the VOSI rubric. (See Appendix A for the final scoring rubric.) The researchers achieved substantial agreement $(K=0.78)$ using this final version of the VOSI rubric to analyze 41 sets of responses from subjects. Four researchers were assigned to score half of the remaining VOSI questionnaires, both pre and post, resulting in two scores per question for each VOSI instrument. When score discrepancies occurred, a third researcher scored the item and the majority score was taken.

Pre and post VOSI survey data were analyzed using the VOSI rubric to assess a respondent's view of scientific inquiry. For quantitative analyses, 'Naïve' views of science inquiry received a score of one; 'Informed' views received a two; and 'Sophisticated' views were scored as a three. An overall VOSI score was calculated for each teacher based on the scores given the responses to each of the questions, which were used in further statistical analyses comparing the two RET programs. Independent t-tests and paired sample t-tests were used to gauge statistical significance between and among group scores.

\section{Results}

\subsection{Does Participation in a Research Experience for Teachers Program Shape Science Teachers' Understanding of Scientific Inquiry?}

As shown in figure 1, which includes data from all teachers participating in both programs, teachers entered the program with a somewhat informed understanding of scientific inquiry (indicated by mean VOSI score for incoming teachers of 1.75 out of 3). Participation in RET programs allowed for the modest development of the teachers' understandings of the nature of scientific inquiry, as measured by changes in their scores on the VOSI instrument (with the mean scores after the program increasing to 2.07). There was a statistically significant difference between teachers' scores before $(\mathrm{m}=1.75 \pm 0.548)$ and after $(2.07 \pm 0.525)$ participation in an RET program $(\mathrm{n}=55), \mathrm{t}(54)=6.67, p<.001$. Thus, teachers enhanced their understanding of inquiry after participating in either of the RET programs.

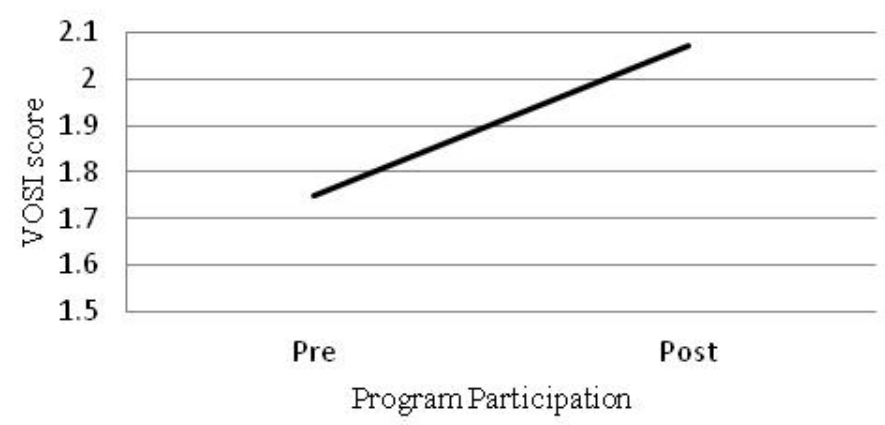

Figure 1. Changes in understanding of scientific inquiry--Whole group 
As shown in figure 2, secondary teachers entered and left the RET experience with a stronger understanding of inquiry (Before: $\mathrm{m}=1.97 \pm 0.563$; After: $\mathrm{m}=2.24 \pm 0.517$ ) than their elementary counterparts (Before: $\mathrm{m}=1.45 \pm$ 0.284; After: $\mathrm{m}=1.82 \pm 0.454$ ), but as shown in figure 2, elementary teachers did experience a notable improvement in their understanding of inquiry. There was a statistically significant change in secondary science teachers' scores before $(1.97 \pm 0.563)$ and after $(2.24 \pm 0.517)$ participation in the program $(\mathrm{n}=33), \mathrm{t}(32)=4.80$, $p<.001$. The elementary teachers showed a statistically significant difference in VOSI scores before $(1.45 \pm 0.284)$ and after $(1.82 \pm 0.454)$ participating in the program $(\mathrm{n}=22), \mathrm{t}(21)=3.82, p<.001$. These data suggest that teachers' knowledge both elementary and secondary changed after having participated in an RET experience. However, a different analysis is needed to determine what aspects of their knowledge is influenced by the RET experience.

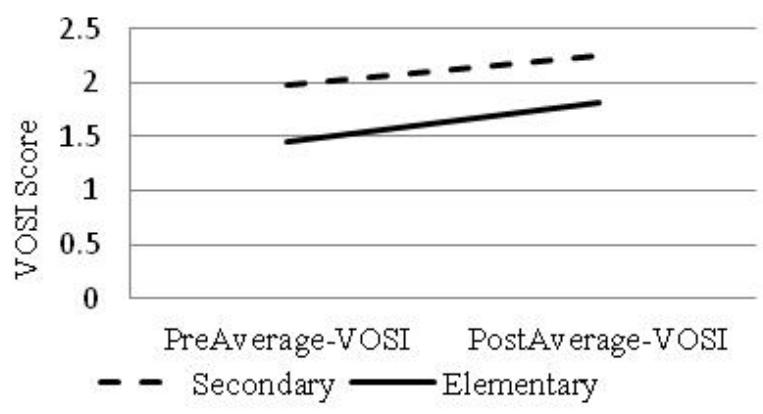

Figure 2. Changes in understanding of scientific inquiry--secondary and elementary grade level teachers

\subsection{What are the Patterns of Change in Teachers' Understanding of Inquiry as a Result of Participation in RET Programs?}

\subsubsection{Elementary Teachers}

Elementary teachers started the summer workshop with fairly naïve understandings regarding the nature of scientific inquiry (see table 2). For each of the constructs measured, the majority of teachers held naïve conceptions, except for of the role of questions in guiding scientific investigations, with $50 \%$ of the elementary teachers held informed conceptions of the role of questions. As they entered the RET experience, the elementary teachers struggled particularly to understand the role of subjectivity and creativity in the procedures of science ( $68 \%$ of the elementary teachers held naïve conceptions of this idea) and the distinction between experiments and other forms of investigation (68\% of the teachers held naïve conceptions on this conception), Also, not surprisingly, many of the elementary teachers entered the RET experience with an emphasis on a singular scientific method (64\% held naïve conceptions about the scientific method and no one held a sophisticated understanding of this construct).

Table 2. Categories of elementary science teachers' VOSI responses before and after RET participation

\begin{tabular}{|c|c|c|c|c|c|c|c|c|c|}
\hline \multirow[b]{3}{*}{ Conception of Inquiry } & \multicolumn{9}{|c|}{ Elementary Teachers } \\
\hline & \multicolumn{3}{|c|}{ Incoming \% } & \multicolumn{3}{|c|}{ Outgoing \% } & \multicolumn{3}{|c|}{ Percentage Change $\%$} \\
\hline & है & 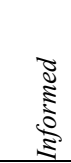 & 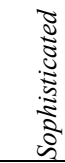 & है & 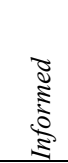 & 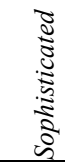 & है & 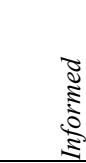 & \\
\hline $\begin{array}{l}\text { Role of Questions in Guiding Scientific } \\
\text { Investigations }\end{array}$ & 41 & 50 & 9 & 18 & 59 & 23 & -23 & 9 & 14 \\
\hline Relationship between data, analysis and evidence & 54 & 41 & 5 & 45 & 32 & 23 & -9 & -9 & 18 \\
\hline $\begin{array}{l}\text { Experiments' distinction from other forms of } \\
\text { investigation }\end{array}$ & 68 & 27 & 5 & 60 & 36 & 4 & -8 & 9 & -1 \\
\hline $\begin{array}{l}\text { Role of subjectivity and creativity in scientific } \\
\text { procedures }\end{array}$ & 68 & 27 & 5 & 23 & 59 & 18 & -45 & 32 & 13 \\
\hline The varied methods of science & 64 & 36 & 0 & 55 & 41 & 4 & -9 & 5 & 4 \\
\hline
\end{tabular}


After their RET experiences, the elementary teachers' views of NOSI became more informed, with the majority holding informed views for the role of questions and the role of subjectivity and creativity and appropriate responses to anomalous data (see table 2). Conceptions which the majority of teachers still held naïve views after program participation included the distinction of experiments and other forms of investigations and recognition of the varied methods employed in science. The elementary teachers' views of the relationship between data, analysis and evidence developed slightly.

Table 3 demonstrates the greatest degree of movement toward a sophisticated understanding of the elements of NOSI was found in elementary teachers' views of the role of subjectivity and creativity. Notable gains were also seen in the role of questions. In contrast, the other conceptions of scientific inquiry showed less robust patterns of change towards sophistication.

Table 3. Directionality of the change in elementary teachers' conceptions of scientific inquiry

\begin{tabular}{|c|c|c|c|c|c|c|}
\hline \multicolumn{7}{|c|}{ Conception of scientific inquiry } \\
\hline Group & $\begin{array}{l}\text { Direction of } \\
\text { Movement }\end{array}$ & $\begin{array}{l}\text { Role of } \\
\text { Questions }\end{array}$ & $\begin{array}{l}\text { Data, } \\
\text { analysis, } \\
\text { evidence }\end{array}$ & $\begin{array}{l}\text { Experiments } \\
\text { vs. other } \\
\text { investigations }\end{array}$ & $\begin{array}{l}\text { Subjectivity } \\
\text { and } \\
\text { Creativity }\end{array}$ & $\begin{array}{l}\text { Varied } \\
\text { Methods } \\
\text { of Science }\end{array}$ \\
\hline \multirow{3}{*}{ Whole } & $\begin{array}{l}\text { Less } \\
\text { Sophisticated }\end{array}$ & 1 & 3 & 4 & 0 & 2 \\
\hline & No Change & 15 & 12 & 11 & 12 & 15 \\
\hline & $\begin{array}{l}\text { More } \\
\text { Sophisticated }\end{array}$ & 6 & 7 & 7 & 10 & 5 \\
\hline \multirow{3}{*}{ SciRes } & $\begin{array}{l}\text { Less } \\
\text { Sophisticated }\end{array}$ & 0 & 1 & 2 & 0 & 0 \\
\hline & No Change & 8 & 7 & 6 & 7 & 9 \\
\hline & $\begin{array}{l}\text { More } \\
\text { Sophisticated }\end{array}$ & 3 & 3 & 3 & 4 & 2 \\
\hline \multirow{3}{*}{ SciPed } & $\begin{array}{l}\text { Less } \\
\text { Sophisticated }\end{array}$ & 1 & 2 & 2 & 0 & 2 \\
\hline & No Change & 7 & 5 & 7 & 5 & 6 \\
\hline & $\begin{array}{l}\text { More } \\
\text { Sophisticated }\end{array}$ & 3 & 4 & 2 & 6 & 3 \\
\hline
\end{tabular}

As shown in Table 4, the differences described above are statistically significant, with the mean of teachers' scores for the two conceptions (role of questions and the role of subjectivity and creativity in inquiry) after the program being statistically different than their scores obtained before the program. No statistically significant differences were found in teachers' understandings of the other conceptions related to scientific inquiry (data, analysis, and evidence, experiments versus other investigations, and the varied methods of science).

Table 4. Comparison of elementary teachers' mean VOSI scores before and after program participation: Paired sample test.

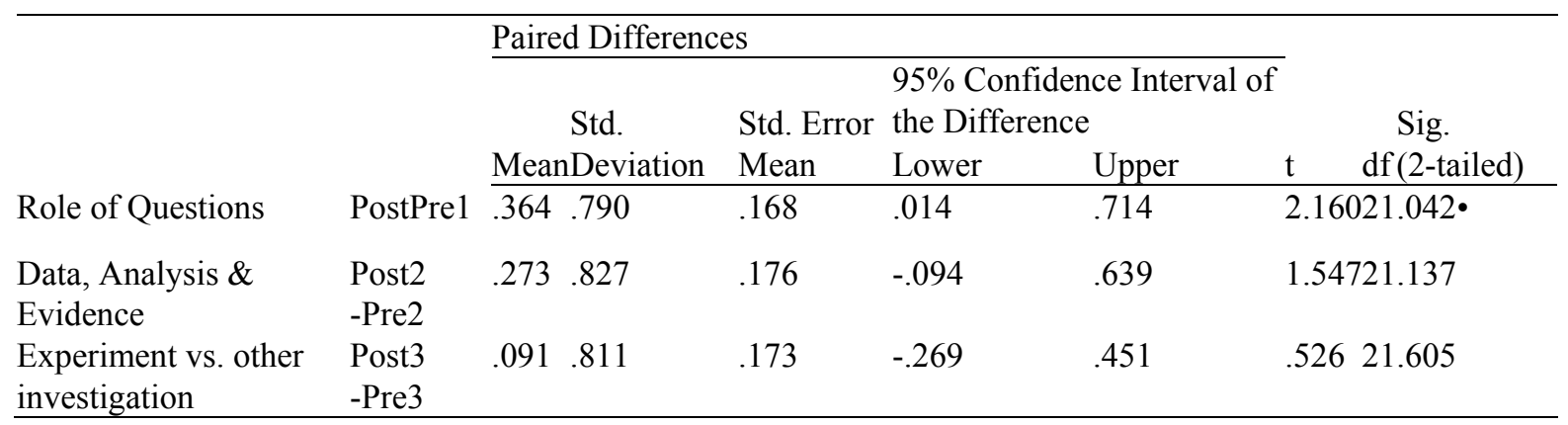




\begin{tabular}{|c|c|c|c|c|c|c|}
\hline $\begin{array}{l}\text { Subjectivity and } \\
\text { Creativity }\end{array}$ & $\begin{array}{l}\text { Post6 } \\
\text {-Pre6 }\end{array}$ & $\begin{array}{ll}.591 & .734\end{array}$ & .157 & .265 & .916 & $3.77521 .001 \bullet$ \\
\hline $\begin{array}{l}\text { Varied Methods of } \\
\text { Science }\end{array}$ & $\begin{array}{l}\text { Post } 4 \\
\text {-Pre4 }\end{array}$ & . 136.560 & .119 & -.112 & .385 & 1.14221 .266 \\
\hline
\end{tabular}

*indicates a statistically significant difference.

\subsubsection{Secondary Teachers}

Secondary teachers entered the summer workshop with more sophisticated understandings of the nature of science than their elementary counterparts (see Figure 2). For each of the constructs measured, there were similar distributions of secondary teachers holding naïve, informed or sophisticated views as seen in Table 5 . The exception to this trend was found in secondary teachers' understandings of the role of questions in guiding the scientific process, with only $9 \%$ of the teachers holding sophisticated view in this area before program participation.

Table 5. Categories of secondary science teachers' VOSI responses before and after RET participation

\begin{tabular}{|c|c|c|c|c|c|c|c|c|c|}
\hline \multirow[b]{3}{*}{ Conception of Inquiry } & \multicolumn{9}{|c|}{ Secondary Teachers } \\
\hline & \multicolumn{3}{|c|}{ Incoming \% } & \multicolumn{3}{|c|}{ Outgoing \% } & \multicolumn{3}{|c|}{$\begin{array}{l}\text { Percentage } \\
\text { Change \% }\end{array}$} \\
\hline & $\overbrace{\bar{z}}^{2}$ & 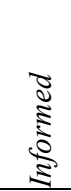 & 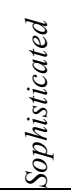 & $\overbrace{\bar{z}}^{2}$ & $\begin{array}{l}\widetilde{\Xi} \\
\text { है } \\
\text { s }\end{array}$ & 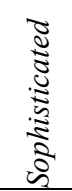 & $\overbrace{\bar{z}}^{2}$ & 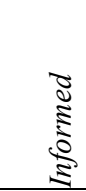 & 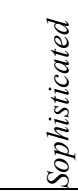 \\
\hline $\begin{array}{l}\text { Role of Questions in Guiding Scientific } \\
\text { Investigations }\end{array}$ & 40 & 51 & 9 & 24 & 45 & 31 & -16 & -6 & 33 \\
\hline $\begin{array}{l}\text { Relationship between data, analysis and } \\
\text { evidence }\end{array}$ & 40 & 33 & 27 & 18 & 48 & 34 & -22 & 15 & 7 \\
\hline $\begin{array}{l}\text { Experiments' distinction from other forms of } \\
\text { investigation }\end{array}$ & 27 & 42 & 31 & 10 & 54 & 36 & -17 & 12 & 5 \\
\hline $\begin{array}{l}\text { Role of subjectivity and creativity in scientific } \\
\text { procedures }\end{array}$ & 22 & 45 & 33 & 12 & 52 & 36 & -10 & 7 & 3 \\
\hline The varied methods of science & 27 & 30 & 43 & 15 & 21 & 64 & -12 & -9 & 21 \\
\hline
\end{tabular}

As shown in table 5, after the professional development experience, the secondary teachers' views of the nature of scientific inquiry became more sophisticated, with the majority holding informed views or sophisticated views for all five conceptions measured after program participation. The conception with the largest gain in secondary teachers was the recognition of the varied methods of science.

Not surprisingly, the greatest degree of movement toward a sophisticated understanding was found in the secondary teachers' understandings of role of questions in science (see table 6). The degree of movement seen in the other conceptions was more ambiguous. Statistically speaking, the secondary teachers' conceptions of inquiry were significantly more sophisticated after program participation for all but one conception concerning the recognition of the role of subjectivity and creativity in science (see table 7). This conception demonstrated the smallest increase in sophisticated understandings after program participation, perhaps due to the already large number of teachers that held a sophisticated understanding of this conception before the program began. 
Table 6. Directionality of Change in Secondary Teachers' Conceptions of Scientific Inquiry

\begin{tabular}{|c|c|c|c|c|c|c|}
\hline Group & $\begin{array}{l}\text { Direction of } \\
\text { Movement }\end{array}$ & $\begin{array}{l}\text { Role of } \\
\text { Questions }\end{array}$ & $\begin{array}{l}\text { Data, } \\
\text { analysis, } \\
\text { evidence }\end{array}$ & $\begin{array}{l}\text { Experiments } \\
\text { vs. other } \\
\text { investigations }\end{array}$ & $\begin{array}{l}\text { Subjectivity } \\
\text { and } \\
\text { Creativity }\end{array}$ & $\begin{array}{l}\text { Varied } \\
\text { Methods } \\
\text { of } \\
\text { Science }\end{array}$ \\
\hline \multirow{3}{*}{ Whole } & $\begin{array}{l}\text { Less } \\
\text { Sophisticated }\end{array}$ & 1 & 3 & 3 & 4 & 2 \\
\hline & No Change & 20 & 19 & 19 & 22 & 20 \\
\hline & $\begin{array}{l}\text { More } \\
\text { Sophisticated }\end{array}$ & 12 & 11 & 11 & 7 & 11 \\
\hline \multirow{3}{*}{ SciRes } & $\begin{array}{l}\text { Less } \\
\text { Sophisticated }\end{array}$ & 1 & 1 & 0 & 3 & 1 \\
\hline & No Change & 9 & 10 & 8 & 8 & 7 \\
\hline & $\begin{array}{l}\text { More } \\
\text { Sophisticated }\end{array}$ & 5 & 4 & 7 & 4 & 7 \\
\hline \multirow{3}{*}{ SciPed } & $\begin{array}{l}\text { Less } \\
\text { Sophisticated }\end{array}$ & 0 & 2 & 3 & 1 & 1 \\
\hline & No Change & 11 & 9 & 11 & 14 & 13 \\
\hline & $\begin{array}{l}\text { More } \\
\text { Sophisticated }\end{array}$ & 7 & 7 & 4 & 3 & 4 \\
\hline
\end{tabular}

Table 7. Comparison of Secondary Teachers' Mean VOSI Scores Before and After Program Participation: Paired Samples Test

Paired Differences

\begin{tabular}{|c|c|c|c|c|c|c|c|c|c|}
\hline & & \multicolumn{6}{|c|}{ Paired Differences } & \multirow[b]{3}{*}{ df } & \multirow{3}{*}{$\begin{array}{l}\text { Sig. } \\
\text { (2-tailed) }\end{array}$} \\
\hline & & \multirow[b]{2}{*}{ Mean } & \multirow{2}{*}{$\begin{array}{l}\text { Std. } \\
\text { Deviation }\end{array}$} & \multirow{2}{*}{$\begin{array}{l}\text { Std. Error } \\
\text { Mean }\end{array}$} & \multicolumn{3}{|c|}{$\begin{array}{l}95 \% \text { Confidence Interval } \\
\text { of the Difference }\end{array}$} & & \\
\hline & & & & & Lower & Upper & $\mathrm{t}$ & & \\
\hline $\begin{array}{l}\text { Role of } \\
\text { Questions }\end{array}$ & $\begin{array}{l}\text { Post1 } \\
\text { Pre1 }\end{array}$ & .364 & .603 & .105 & .150 & .577 & 3.464 & 32 & $.002 *$ \\
\hline $\begin{array}{l}\text { Data, Analysis } \\
\text { \& Evidence }\end{array}$ & $\begin{array}{l}\text { Post5 } \\
\text { Pre5 }\end{array}$ & .273 & .674 & .117 & .034 & .512 & 2.324 & 32 & $.027 *$ \\
\hline $\begin{array}{l}\text { Experiments } \\
\text { vs. other } \\
\text { investigations }\end{array}$ & $\begin{array}{l}\text { Post3 } \\
\text { Pre3 }\end{array}$ & .242 & .614 & .107 & .025 & .460 & 2.268 & 32 & $.030^{*}$ \\
\hline $\begin{array}{l}\text { Subjectivity } \\
\text { and Creativity }\end{array}$ & $\begin{array}{l}\text { Post4 } \\
\text { Pre4 }\end{array}$ & .121 & .781 & .136 & -.156 & .398 & .892 & 32 & .379 \\
\hline $\begin{array}{l}\text { Varied } \\
\text { Methods of } \\
\text { Science }\end{array}$ & $\begin{array}{l}\text { Post2 } \\
\text { Pre2 }\end{array}$ & .333 & .816 & .142 & .044 & .623 & 2.345 & 32 & $.025^{*}$ \\
\hline
\end{tabular}

*indicates a statistically significant difference

4.3 Is There a Difference Between the Impact of the Two RET Programs (Sciped and Scires) in Shaping Elementary and Secondary Teachers' Understanding of Scientific Inquiry?

Comparing the influence of the two different RET programs on the development of teachers' understanding of scientific inquiry, both programs facilitated improvement in participants' understanding of scientific inquiry, and 
both programs were similarly effective in supporting this development. (See figure 3). There was no statistically significant difference between the two programs in terms of teachers' incoming understanding of inquiry [SciPed $(\mathrm{m}=1.89 \pm 0.517) ;$ SciRes $(\mathrm{m}=1.60 \pm 0.551) ; \mathrm{t}(53)=1.93, \mathrm{p}>.05]$. Likewise, at the end of the program there was no significant difference between the SciPed $(m=2.14 \pm 0.465)$ and the SciRes $(m=1.99 \pm 0.582)$ in their understanding of scientific inquiry, $t(53)=1.132, p>.05$. Given the difference in elementary and secondary teachers understanding of scientific inquiry, a different picture may be found when these grade levels are teased apart.

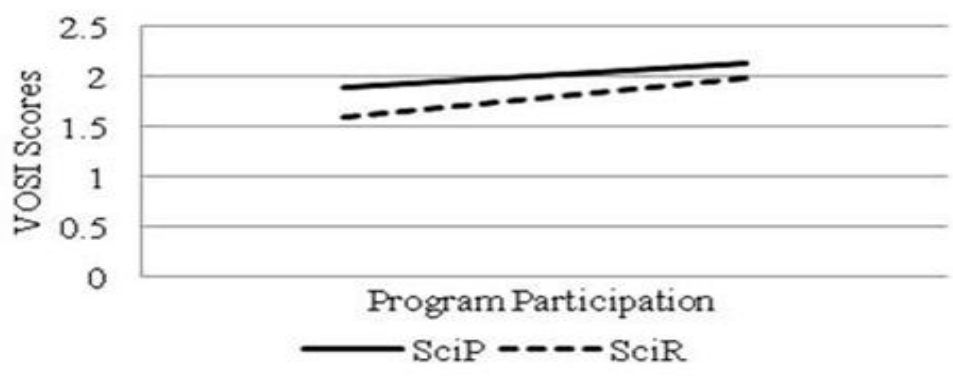

Figure 3. Program comparison of changes in understanding of scientific inquiry

\subsubsection{Elementary Teachers}

When we examine the data for the elementary teachers and compare the influence of the two different RET programs on their understanding of scientific inquiry, the data suggest that both programs allowed for the development of teachers' understandings. (See figure 4). As suggested in figure 4, there was no statistically significant difference between two programs in terms of teachers' incoming understandings [SciPed $(\mathrm{m}=1.43 \pm$ $0.34)$; SciRes $(\mathrm{m}=1.40 \pm 0.27) ; \mathrm{n}=22, t(20)=.197, p>.05$. Thus, the two groups of teachers were remarkably similar in their understanding of scientific inquiry before the beginning the program. It is important to note, there was no difference in the elementary teachers' understanding after the program participation [SciPed $(\mathrm{m}=1.77 \pm$ $0.265)$; SciRes $(\mathrm{m}=1.86 \pm 0.561) ; \mathrm{n}=22 t(20)=.49, p>.05]$. Thus, there were no differences in the influence the two contrasting RET programs had on elementary teachers' understanding of scientific inquiry-they both were similarly effective.

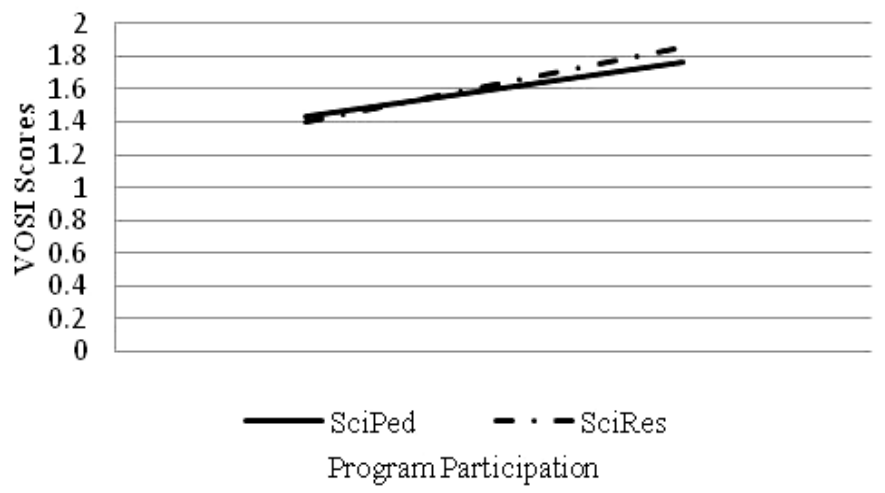

Figure 4. Program comparison of elementary teachers' understanding of scientific inquiry

\subsubsection{Secondary Teachers}

The data from secondary teachers suggest that both programs allowed for their understanding of scientific inquiry to improve (See figure 5). However, it is important to note that there was a difference between the incoming understanding of secondary teachers across the two programs, with teachers entering the SciPed program demonstrating stronger knowledge of scientific inquiry than teachers entering the SciRes program [Secondary SciPed $(\mathrm{m}=2.18 \pm 0.38)$, SciRes $(\mathrm{m}=1.76 \pm 0.66)]$ a difference that is statistically significant $t(31)=$ 2.26, $p<.05$. This difference was maintained in terms of teachers' knowledge after the program, with the Secondary teachers in the SciPed program $(\mathrm{m}=2.40 \pm .389)$ demonstrating a stronger knowledge of scientific 
inquiry than the teachers in the SciRes program $(\mathrm{m}=2.08 \pm .599),[t(31)=1.85, p>.05]$ after the end of the RET participation. Thus, the SciPed program attracted teachers with a stronger understanding of scientific inquiry than the SciRes program. Although both programs allowed for the further development of teachers' understanding of inquiry, the initial difference in understandings of inquiry between participants in the programs was maintained.

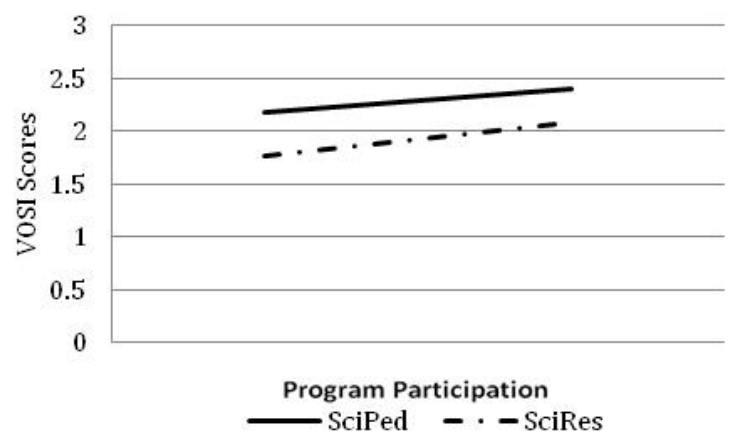

Figure 5. Program comparison of changes in secondary teachers' understanding of scientific inquiry

\section{Discussion}

These findings further support the limited but growing descriptions of teachers' understandings of the nature of science. Echoing the teacher featured in Lederman and Lederman (2008), many of the elementary teachers in this study entered the professional development experience with the understanding that science follows a singular scientific method, as well as failing to distinguish experiments from other means of investigations in science, and understanding science to be a largely objective, uncreative process.

The secondary teachers in this study entered the professional development with a more sophisticated conceptualization of scientific inquiry than their elementary counterparts, holding more informed views of each of the concepts measured (Loucks-Horsley, Love, Stiles, Mundry, \& Hewson, 2003). Secondary teachers who selected to participate in a relatively extensive professional development program (six weeks in duration) held an understanding of scientific inquiry that was overall informed at best. The fewest number of secondary teachers held a sophisticated conception of the role of questions in guiding scientific investigations, and the greatest number of teachers held a sophisticated understanding of the varied methods of science.

These findings suggest that both elementary and secondary teachers' understandings of scientific inquiry are limited, echoing what has been described for teachers' understanding of the nature of science (Lederman \& Lederman, 2004) and their understandings of classroom inquiry (Abrams et al., 2008). Given the role teachers understandings are thought to play in shaping both what and how science teachers enact curriculum (Schwarz, Weserlund, Garcia \& Taylor, 2010), it is clear that efforts to further support science teachers' conceptual development continued to be needed.

The RET programs designed to support teachers' conceptual development around inquiry examined in this study were successful in supporting aspects of teachers' conceptual growth. For elementary teachers, development was seen in teachers' understandings of the role of questions in science and the role that subjectivity and creativity play in the processes of science, and particularly limited learning was documented around conceptions of experiments and their distinctions from other means of investigations and the varied methods of science (as opposed to a singular scientific method). This limited number of teachers that experienced conceptual growth in these two areas suggest that either these conceptions are particularly difficult to influence or the structure of the RET experiences was not conducive to their development for elementary teachers.

For secondary teachers, the RET supported growth in the role of questions, the relationship of data and evidence, the distinction of experiments and other means of investigations, and the varied methods of science. The limited growth seen in secondary teachers' conceptions around the role of subjectivity and creativity in the processes of science could suggest that this conception was particularly difficult to influence or that the RET experience was not the optimal vehicle for instruction around this conception.

The larger amount of growth experienced by secondary teachers compared to elementary teachers is not surprising in light of their deep content knowledge. Their more robust content knowledge at the outset of either 
RET program made them primed for change as a result of the experience. Perhaps elementary teachers' greater naiveté about the nature of scientific inquiry caused them to be less ready to learn about certain elements of scientific inquiry than their secondary peers. That said, the RET experiences were successful in supporting the learning of elementary teachers. This finding is particularly important since historically, in earlier years, RET experiences were often reserved for secondary teachers, as the experience was considered too challenging for their elementary colleagues.

These findings also suggest that successful RET programs are only moderately successful in improving teachers' understandings of scientific inquiry. Teachers' participation in scientific inquiry at the "elbow" of a scientist was productive in supporting moderate growth in teachers' views about scientific inquiry (Barab \& Hay, 2001). However, the limited number of teachers that exited the program demonstrating a sophisticated understanding of scientific inquiry suggests that there is "room" for improvement in the RET experience in terms of its effectiveness in this regard. Indeed, it was hoped that the comparison of the effectiveness of the two very different RET programs would provide some insight into the optimal structure of an RET to support teachers' understanding of scientific inquiry.

There was no difference in the degree to which the different RET experiences supported teachers' knowledge of scientific inquiry, both being moderately successful. Thus, this analysis sheds no light on what sort of experiences are most productive for elementary teachers as there were no obvious differences in the conceptual shifts either program supported. Although both the SciRes and SciPed programs supported the development of secondary teachers' understandings of scientific inquiry, the secondary teachers in the SciPed program exited the program with a stronger knowledge of scientific inquiry than the teachers in the SciRes program. However, these teachers also entered the program with stronger understandings of this construct. The similar slopes seen in figure 5, and the similar patterns of change in conceptions seen in table 7 suggests that both programs supported teacher learning about scientific inquiry. However, the SciPed program was more successful in helping move teachers toward a sophisticated understanding of the role of questions and the relationship of scientific data and evidence. These shifts may be explained by these teachers' participation in all stages of scientific investigations as the science they participated in was in the pursuit of a question they themselves posed as opposed to joining the exploration of a pre-established scientific investigation, a feature of the SciRes program.

In contrast, participation in the SciRes program was more successful in supporting teachers' move toward a sophisticated understanding of the distinction of experiments and other forms of investigation and the varied methods of science. It is plausible that these shifts were enabled by teachers' exposure to a wide range of studies conducted at the International Magnetic Laboratory during their sharing sessions; something not featured in the SciPed program more uniform, experimental, marine focused experience.

\section{Implications}

Given these findings, it seems appropriate to consider the limited degree of conceptual development experienced by both elementary and secondary teachers despite their engagement in extended, intensive, research-based experiences. This limited degree of learning can perhaps be explained by extending the work of Schwartz, Westerlund, Garcia, \& Taylor (2010) from NOS to scientific inquiry. They describe that the "nagging assumption that participation in authentic scientific inquiry is sufficient to engender desired conceptions of NOS" (p. 29) needs to be laid to rest. The research presented suggests that this notion should be extended beyond the nature of science: that is, a sophisticated understanding of the nature of scientific inquiry will not be automatically learned simply by participation in authentic scientific inquiry. Instead, if such learning is to be fostered, it must be the focus of instruction.

Our findings agree others (Barab \& Hay, 2001; Blanchard \& Sampson, 2011; Capps et al., 2012) who suggest that research experiences and other professional development experiences should be modified to include a more explicit component, to help teachers make sense of their experiences in terms of their own conceptual development. Too, the mixed results obtained when the SciRes and SciPed program suggests that a blend of these two approaches, one that allows teachers to experience all parts of a scientific investigation, be supported in reflecting on that experience, as well as have exposure to a wide range of research approaches may also be required if a sophisticated understanding of scientific inquiry is a goal of the RET program.

Finally, while this research speaks to the degree to which RETs are successful in supporting teachers' learning about inquiry, they fail to allow us to understand the relationship of that knowledge to teacher knowledge of classroom inquiry (as has been posited in the literature), or their classroom practices (Capps et al., 2011). If science educators are to better support teachers' professional development as a vehicle to influence the learning 
of students in science classrooms (Crawford, 2000), this more nuanced line of inquiry warrants sincere attention from researchers and educators.

This research was funded by the National Science Foundation, DISCOVERY RESEARCH K-12 Program, award number \#0553769.

\section{References}

Abrams, E., Southerland, S. A., \& Silva, P. (Eds.). (2008). Inquiry in the classrooms: Realities and Opportunities Greenwich, CT: Information Age Publishing.

Akerson, V. L., Abd-El-Khalick, F., \& Lederman, N. G. (2000). Influence of a reflective explicit activity-based approach on elementary teachers' conceptions of nature of science. Journal of research in Science Teaching, 37(4), 295-317.

American Association of Advancement of Science. (1993). Benchmarks for Science Literacy. Oxford University Press. New York. Retrieved from http://www.project2061.org/publications/bsl/online/ch1/ch1.htm

Barab, S., \& Hay, K. (2001). Doing science at the elbows of experts: Issues related to the science apprenticeship Camp. Journal of Research in Science Teaching, 38(1), 70-102.

Blanchard, M., \& Sampson, V. (2011). A recipe for an effective research experience for teachers (RET): Take two scientists, mix in the national reform goals, blend with authentic research experiences, and add a specific model of inquiry-based instruction. Paper Presented at the Annual Meeting of the National Association for Research in Science Teaching, Orlando, FL, April, 2011.

Blanchard, M., Southerland, S. A., \& Granger, D. E. (2009). No silver bullet for inquiry: Making sense of teacher change following an inquiry-based research experience for teachers. Science Education, 93(2), 322-360.

Cakir, M. (2004). Exploring Prospective Secondary Science Teachers' Understandings of Scientific Inquiry and Mendelian Genetics Concepts Using Computer Simulation. Ph. D. Dissertation. The Pennsylvania State University.

Capps, D. K., Crawford, B. A., \& Constas, M. A. (2012). A review of empirical literature on inquiry professional development: Alignment with best practices and a critique of the findings. Journal of Science Teacher Education, 23(3), 291-318. http://dx.doi.org/10.1007/s10972-012-9275-2

Cohen, J. (1968). Weighted kappa: nominal scale agreement with provision for scaled disagreement or partial credit. Psychological Bulletin, 70, 213-220.

Crawford, B. A. (2000). Embracing the essence of inquiry: New roles for science teachers. Journal of Research in Science Teaching, 37, 916-937.

Duschl, R., Schwingruber, H.A., \& Shouse, A.W. (2007). Taking Science to School: Learning and Teaching Science in Grades K-8. Committee on Science Learning, Washington, D.C.: National Academy Press.

Golden, B. W., Enderle, P. J., Uysal Bahbah, S., Nguyen, G. N., Koska, B., Roseler, K., Southerland, S. A., \& Saka, Y. (2011, April). Authentic to Whom? A synthesis of research from 3 years of a 5 year comparison of two different models for RET's. Paper presented at the National Association for Research in Science Teaching. Orlando, FL.

Granger, D. E., \& Herrnkind, W. F. (1999). Field Biology Research Experiences for Teachers: An Effective Model for Inquiry-Based Science Teaching. National Science Foundation Proposal No. ESI-9819431, Author: Tallahassee, FL.

Kennedy, L.M., Yezierski, E.J., \& Herrington, D.G. (2008). Whose science is it anyway? Models of science according to chemistry students, faculty, and teachers. Science Educator, 17(1).

Khishfe, R., \& Abd-El Khalick, F. (2002). Influence of Explicit and Reflective versus Implicit Inquiry-Oriented Instruction on Sixth Graders' Views of Nature of Science. Journal of Research in Science Teaching, 39(7), 551-578.

Lederman, J. S., \& Lederman, N. G. (2004). Early Elementary Students' and Teacher's Understandings of Nature of Science and Scientific Inquiry: Lessons Learned from Project ICAN. Paper Presented at the Annual Meeting of the National Association for Research in Science Teaching, Vancouver, British Columbia, April, 2004. 
Loucks-Horsley, S., Love, N., Stiles, K. E., Mundry, S., \& Hewson, P. W. (2003). Designing professional development for teachers of science and mathematics (2nd ed.). Thousand Oaks, CA: Corwin Press.

Schwartz, R. S., Lederman, N., \& Lederman, N. (2008, April). An instrument to assess views of scientific inquiry: The VOSI Questionnaire. Paper presented at the international conference of the National Association for Research in Science Teaching, Baltimore, Maryland.

Schwartz, R. S., Weserlund, J. F., Garcia, D. M., \& Taylor, T. A. (2010). The impact of full immersion scientific research experiences on teachers' views of the nature of science. Electronic Journal of Science Education, 14(1). Retrieved from http://ejse.southwestern.edu/article/view/7325/5623

\section{Appendix A}

The VOSI Questionnaire and Scoring Rubric

\section{Questions and Scoring Rubric-Questions Common to Elementary and Secondary}

1. What types of activities do scientists (e.g., biologists, chemists, physicists, earth scientists) do to learn about the natural world? Discuss how scientists (biologists, chemists, earth scientists) do their work.

NAÏVE

The answer focuses on pursuit of truth and/or The Science Method with no mention of the pursuit of scientific questions and/or description of only one type of scientific activity.
INFORMED

The answer focuses on accurate description of at least 2 types of scientific work/process/activity, but little mention of pursuit of questions.
SOPHISTICATED

The answer focuses on science starting with pursuit of scientific questions, and may also mention multiple (more than two) accurate descriptions of scientific work.

\section{2. (a) What does the word "data" mean in science?}

(b) Is "data" the same or different from "evidence"? Explain. Assess question two as a whole, looking at both $\mathrm{A}$ and $\mathrm{B}$.

\begin{tabular}{lll}
\hline \multicolumn{1}{c}{ NAÏVE } & \multicolumn{1}{c}{ INFORMED } & \multicolumn{1}{c}{ SOPHISTICATED } \\
\hline $\begin{array}{l}\text { Answers include: data are only } \\
\text { numerical and/or evidence and } \\
\text { data are equivalent. }\end{array}$ & $\begin{array}{l}\text { Data can be both qualitative and } \\
\text { quantitative; data and evidence are } \\
\text { not the same, but the two are not } \\
\text { adequately differentiated. }\end{array}$ & $\begin{array}{l}\text { Answers make the distinction } \\
\text { between evidence and data, in } \\
\text { that evidence is the subjective } \\
\text { product of data analysis. }\end{array}$ \\
\hline
\end{tabular}

3. A person interested in birds looked at hundreds of different types of birds who eat different types of food. He noticed that birds who eat similar types of food tended to have similar shaped beaks. For example, birds who eat hard shelled nuts have short, strong beaks, and birds who eat insects from tide pools have long, slim beaks. He concluded that there is a relationship between beak shape and the type of food birds eat.

a. Do you consider this person's investigation to be an experiment? Please explain why or why not.

b. Do you consider this person's investigation to be scientific? Please explain why or why not by describing what it means to do something "scientifically."

This investigation is / is not (circle one) scientific because....

NAÏVE INFORMED

SOPHISTICATED

\footnotetext{
Identifies scenario is an experiment; or experiments are needed for an investigation to be considered scientific; or it is not characterized as an experiment but poorly or incorrectly elaborated.
}

Answers include that science is not necessarily experimental.
Answers include the idea that science works via multiple methods and successfully distinguish between the experiments and other forms of investigations.

4. a) If several scientists, working independently, ask the same question and follow the same procedures to collect data, will they necessarily come to the same conclusions? Explain why or why not. 
b) If several scientists, working independently, ask the same question and follow different procedures to collect data, will they necessarily come to the same conclusion? Explain why or why not.

c) Does your response to (a) change if the scientists are working together? Explain.

d) Does your response to (b) change if the scientists are working together?

\begin{tabular}{lll}
\hline \multicolumn{1}{c}{ NAÏVE } & \multicolumn{1}{c}{ INFORMED } & \multicolumn{1}{c}{ SOPHISTICATED } \\
\hline $\begin{array}{l}\text { Same procedures produce same } \\
\text { conclusion; different procedures } \\
\text { produce different results, etc. }\end{array}$ & $\begin{array}{l}\text { Recognize that same procedures } \\
\text { may produce different conclusion, } \\
\text { with no elaboration, or } \\
\text { unsophisticated elaboration. }\end{array}$ & $\begin{array}{l}\text { Recognize that same procedures } \\
\text { may produce different results } \\
\text { given the role creativity and } \\
\text { subjectivity play in science; may } \\
\text { also include a recognition of the }\end{array}$ \\
& & $\begin{array}{l}\text { strengths and/or weaknesses of } \\
\text { working together. }\end{array}$ \\
\hline
\end{tabular}

\section{Question Specifically for Elementary Teachers}

5(e). The "scientific method" is often described as involving the steps of making a hypothesis, identifying variables (dependent/independent), designing an experiment, collecting data, reporting results. Do you agree that to do good science, scientists must follow the scientific method?

YES, scientists must follow the scientific method

NO, there are many scientific methods

If YES (you think all scientific investigations must follow a standard set of steps or method), describe why scientists must follow this method. If NO (you think there are multiple scientific methods), explain how the methods differ and how they can still be considered scientific.

\begin{tabular}{lll}
\hline \multicolumn{1}{c}{ NAÏVE } & \multicolumn{1}{c}{ INFORMED } & \multicolumn{1}{c}{ SOPHISTICATED } \\
\hline YES, answers describe that & No, answers recognized multiple & No, answers elaborate and \\
scientists must follow & methods of science, but incorrectly & give accurate representations \\
THE scientific method. & $\begin{array}{l}\text { characterize or do not differentiate } \\
\text { between methods. }\end{array}$ & science. \\
\hline
\end{tabular}

\section{Question Specifically for Secondary Teachers}

5(s). How do scientists decide what and how to investigate? Describe all the factors you think influence the work of scientists. Be as specific as possible.

\begin{tabular}{lll}
\hline \multicolumn{1}{c}{ NAÏVE } & \multicolumn{1}{c}{ INFORMED } & \multicolumn{1}{c}{ SOPHISTICATED } \\
\hline $\begin{array}{l}\text { Answers focus only on The } \\
\text { Scientific Method and scientists' } \\
\text { interest. }\end{array}$ & $\begin{array}{l}\text { Describes that scientists follow on } \\
\text { THE Scientific Method, but list } \\
\text { one other factor influencing the }\end{array}$ & $\begin{array}{l}\text { Describes various approaches } \\
\text { (beyond a singular scientific } \\
\text { method) that scientists take in } \\
\text { selection of topic other than } \\
\text { scientist interest. }\end{array}$ \\
& & $\begin{array}{l}\text { their work, and cites at least two } \\
\text { factors influencing the selection } \\
\text { of topic for investigation other } \\
\text { than interest. }\end{array}$ \\
\hline
\end{tabular}

